\title{
Ocena mikrostruktury doczołowych złączy spawanych wiązką lasera stali wysokowytrzymałej
}

\author{
Evaluation of laser beam butt welded joints \\ of high-strength steel
}

\section{Streszczenie}

W artykule przedstawiono charakterystykę stali konstrukcyjnych o podwyższonej i wysokiej wytrzymałości. Omówiono mechanizmy umocnienia stali zapewniające korzystne właściwości mechaniczne. Przedstawiono wyniki badania mikrostruktury złączy doczołowych stali o gwarantowanej granicy plastyczności $1300 \mathrm{MPa}$ wykonanych wiązką lasera bez materiału dodatkowego. W celu scharakteryzowania struktury przeprowadzono badania wizualne, makro- i mikroskopowe oraz pomiary twardości w przekroju poprzecznym złącza.

Słowa kluczowe: stal wysokowytrzymała; spawanie wiązką lasera; mikrostruktura

\section{Abstract}

The paper presents characterization of structural highstrength steels and the fundamentals of steel strengthening and hardening to guarantee good mechanical properties. Moreover, the microstructure evaluation of laser beam butt welded joints of steel with yield strength $1300 \mathrm{MPa}$ were carried out and the results were presented. In research the visual testing, macro- and microscopic analysis and hardness measurement were carried out.

Keywords: high-strength steel; laser beam welding; microstructure

\section{Wstęp}

Stale konstrukcyjne o podwyższonej i wysokiej wytrzymałości stosowane są dość powszechnie w różnych gałęziach przemysłu, m.in. budownictwie, transporcie lądowym i morskim oraz energetyce. Niemniej, wraz ze wzrostem granicy plastyczności, ilość wyrobów, w których takie materiały są stosowane maleje. Zastosowanie stali o podwyższonej i wysokiej wytrzymałości wynika głównie z korzystnych właściwości mechanicznych utrzymywanych nawet do $-60^{\circ} \mathrm{C}$, ale nierzadko wzrostowi granicy plastyczności towarzyszy spadek ciągliwości, plastyczności, spawalności i odporności na korozję. Rozwój technologii metalurgicznych, obróbki plastycznej i cieplnej obserwowany od lat 80 . XX w. pozwala na uzyskiwanie blach i rur o wysokiej wytrzymałości bez obniżenia właściwości plastycznych, a granica plastyczności wynosi nawet $1300 \mathrm{MPa}$. Co więcej, sam efekt podwyższonej wytrzymałości nie jest uzyskiwany dzięki złożonemu składowi chemicznemu stali, ale głównie procesom obróbki cieplno-mechanicznej podczas wytwarzania wyrobów hutniczych. Wysoką wytrzymałość, a częściowo również wzrost udarności uzyskuje się podczas ulepszania cieplnego w wyniku uzyskania struktury martenzytu odpuszczonego lub martenzytyczno-bainitycznej, a dobrą plastyczność w wyniku rozdrobnienia ziarna.

Ubogi w składniki stopowe skład chemiczny, a także obniżona zawartość węgla (poniżej 0,2\%) wskazują, że stale te cechują się dobrą spawalnością. Jest to jeden z kluczowych atrybutów stali wysokowytrzymałych dla zastosowań w wielu dziedzinach przemysłu.

W pracy przedstawiono charakterystykę stali konstrukcyjnych w oparciu o normy przedmiotowe w zakresie dostawy walcowanych wyrobów hutniczych (PN-EN 10025) wraz z charakterystyką wybranych ich cech szczególnych w oparciu o wiedzę ogólną oraz wyniki oceny mikroskopowej i pomiarów twardości doczołowego złącza spawanego stali wysokowytrzymałej o gwarantowanej granicy plastyczności $1300 \mathrm{MPa}$. Badana stal należy do grupy stali obrabianych cieplnie na etapie wytwarzania i nie została ujęta w normie PN-EN 10025-6 „Wyroby walcowane na gorąco ze stali konstrukcyjnych - Część 6: Warunki techniczne dostawy wyrobów płaskich o podwyższonej granicy plastyczności w stanie ulepszonym cieplnie".

Dr inż. Lechosław Tuz, mgr inż. Krzysztof Pańcikiewicz, mgr inż. Łukasz Rakoczy - Akademia Górniczo Hutnicza, mgr inż. Krzysztof Sulikowski - Roboty Przemysłowe.

Autor korespondencyjny/Corresponding author. Ituz@agh.edu.pl 


\section{Charakterystyka stali konstrukcyjnych}

Stale konstrukcyjne znajdują zastosowanie w budownictwie, środkach transportu lądowego i morskiego. Ich szerokie zastosowanie wynika w znacznej mierze dzięki spełnieniu następujących wymagań:

- odpowiednio wysokiej granicy plastyczności,

- dobrej spawalności,

- dobrej odkształcalności (formowalności) na zimno,

- wysokiej odporności na kruche pękanie i niskie temperatury przejścia w stan kruchy,

- stosunkowo niskich kosztów wytwarzania.

Wymagania te spełniają między innymi niskowęglowe stale drobnoziarniste o podwyższonej wytrzymałości i niskostopowe stale o wysokiej wytrzymałości.

Duża rozpiętość granicy plastyczności i wytrzymałości na rozciąganie ulega obniżeniu wraz ze wzrostem wytrzymałości. Znane, ale rzadko powszechnie stosowane, są stale o granicy plastyczności od $1650 \mathrm{MPa}$ do $1850 \mathrm{MPa}$ i wytrzymałości na rozciąganie od $1700 \mathrm{MPa}$ do nawet $2000 \mathrm{MPa}$. Tak wysoka wytrzymałość powoduje, że określane są grupą stali o wysokiej wytrzymałości.

W stalach niestopowych o wysokiej wytrzymałości kluczowym pierwiastkiem jest węgiel, który zapewnia odpowiednio wysoką wytrzymałość. Z kolei, w stalach dobrze spawalnych, zawartość węgla nie powinna przekraczać $0,2 \%$ wag. Powoduje to, że konieczność spełnienia warunku dobrej spawalności ogranicza możliwość stosowania zbyt dużej zawartości węgla, co przekłada się na ograniczone właściwości mechaniczne wyrobów hutniczych przeznaczonych na elementy konstrukcji spawanych. Istotne są zatem inne sposoby podwyższania wytrzymałości stali konstrukcyjnych m.in. [2]:

- podwyższanie granicy plastyczności za pomocą rozdrobnienia ziarna ferrytu,

- umocnienie ferrytu przez dodatki stopowe tworzące z żelazem roztwór stały,

- umocnienie ferrytu za pomocą dyspersyjnych wydzieleń związków chemicznych takich pierwiastków chemicznych jak aluminium, niob, tytan czy wanad,

- umocnienie dyslokacyjne ferrytu,

- przemiany fazowe tj. w szczególności bainityczną i martenzytyczną,

- odpowiednią obróbkę cieplno-plastyczną np. walcowanie z kontrolowanymi temperaturami,

- ulepszanie cieplne,

- zgniot na zimno martenzytu niskowęglowego,

- dyspersyjne utwardzanie martenzytu niskowęglowego $\mathrm{np}$. w stalach typu maraging,

- inne sposoby.

Podwyższanie granicy plastyczności za pomocą rozdrobnienia ziarna ferrytu opisuje między innymi zależność HallaPetacha, wg której granica plastyczności jest sumą oporów ruchu dyslokacji i ilorazu stałej k przez pierwiastek drugiego stopnia wielkości ziarna ferrytu. Opisuje to następująca zależność matematyczna:

$\sigma_{\mathrm{y}}=\sigma_{\mathrm{i}}+\mathrm{k}_{\mathrm{y}} \cdot \mathrm{d}^{-1 / 2}$

gdzie:

$\sigma_{y}$ - granica plastyczności,

$\sigma_{i}-$ opór ruchu dyslokacji,

$\mathrm{k}_{\mathrm{y}}$ - stała,

d - wielkość ziarna ferrytu.

Drugim czynnikiem istotnym dla spawalnych stali konstrukcyjnych jest ich plastyczności w określonej temperaturze. Dotyczy to przede wszystkim temperatury obniżonej, charakterystycznej dla konkretnych wymagań stawianych stali. Może ona w uzasadnionych przypadkach wynosić nawet $-60^{\circ} \mathrm{C}$, czyli dla rejonów eksploatacji w okolicach koła podbiegunowego. Temperaturę przejścia w stan kruchy opisuje się albo przez sposób ilościowy zależny, tak jak to ma miejsce w równaniu Halla-Petcha, od wielkości ziarna ferrytu, albo wyraża się w oparciu o pomiar energii zaabsorbowanej i niezbędnej dla złamania próbki przez młot o określonej energii kinetycznej. Realizowane jest to w oparciu o znormalizowaną próbę udarności. Porównanie zależności odnoszących się do wielkości ziarna wskazuje, że wraz ze spadkiem wielkości ziarna ferrytu obniża się temperatura przejścia w stan kruchy.

W procesach metalurgicznych wytwarzania stali kontrolę wielkości ziarna można przeprowadzać przed dodawanie określonych pierwiastków do stali lub cząstek innej fazy, na przykład AIN, czy NbC. Obserwowany jest wówczas efekt, że wraz ze zmniejszaniem się wielkości drugiej fazy (rozdrobnieniem) i ze zwiększaniem się jej udziału objętościowego w stali, tym drobniejsze jest ziarno ferrytu.

Drugi ze wskazanych mechanizmów umocnienia stali, czyli umocnienie roztworu stałego ferrytu, zależy od następujących czynników [2]:

- różnicy promieni atomowych pierwiastka rozpuszczonego i osnowy,

- zaburzenia struktury elektronowej roztworu w wyniku rozpuszczenia innego pierwiastka.

Wskazuje to, że w zależności od składnika stopowego obserwowany będzie efekt wzrostu wytrzymałości lub spadku. Za wzrost wytrzymałości na rozciąganie odpowiada krzem (Si), molibden (Mo), mangan (Mn), miedź ( $\mathrm{Cu})$ i nikiel (Ni), a chrom (Cr) powoduje spadek wytrzymałości na rozciąganie. Zależność stężenia poszczególnych pierwiastków stopowych w stali stanowi liniową zależność względem wytrzymałości na rozciąganie tej stali [2].

Wskazane w powyżej przywołanych mechanizmach podniesienia właściwości mechanicznych stali niestopowych efekty występują również podczas utwardzania wydzieleniowego. W tym przypadku wykorzystuje się dyspersyjne cząsteczki obcej (drugiej) fazy do zwiększenia oporu ruchu dyslokacji. Drugą fazę stanowią najczęściej dyspersyjne wydzielenia węglikoazotków niobu, wanadu i tytanu. Im drobniejsze są wydzielenia i im większy jest ich udział objętościowy, tym większa jest granica plastyczności stali.

Podczas umacniania dyslokacyjnego występuje wzrost gęstości dyslokacji na skutek zwiększania szybkości chłodzenia. Zmiana szybkości powoduje obniżenie temperatury przemiany austenitu w ferryt, a w konsekwencji rozdrobnienie ziarna i wzrost granicy plastyczności oraz wytrzymałości na rozciąganie.

Same przemiany fazowe także mogą spowodować wzrost wytrzymałości, ale produkty przemiany zależą od jej temperatury i składu chemicznego stali. Ogólnie przyjmuje się, że im niższa temperatura przemiany, tym efekt umocnienia jest większy. Obniżanie temperatury przemiany powoduje silne rozdrobnienie produktów przemiany, co obserwowane jest w wielu gatunkach stali zarówno niskostopowych stalach ferrytyczno-perlitycznych o wysokiej wytrzymałości, jak i niskostopowych stalach bainitycznych i martenzytycznych. Niska temperatura przemiany sprzyja również wzrostowi gęstości dyslokacji i dyspersji wydzielających się faz, ale również przesyceniu roztworu stałego. Stąd większość stali o wysokiej wytrzymałości charakteryzuje się strukturą bainityczną. 
W tablicy I przedstawiono skład chemiczny i wybrane właściwości mechaniczne konstrukcyjnych stali niestopowych wg ogólnych warunków technicznych dostawy dla wyrobów walcowanych na gorąco (PN-EN 10025-1) oraz wyrobów walcowanych na gorąco ze stali konstrukcyjnych dla wyrobów płaskich o podwyższonej granicy plastyczności w stanie ulepszonym cieplnie (PN-EN 10025-6). Dla stali o wysokiej wytrzymałości z gwarantowaną minimalną granicą plastyczności $1100 \mathrm{MPa}$ i $1300 \mathrm{MPa}$ wskazano dane wg danych producentów tych stali, odpowiednio SSAB i TyssenKrup Steel.

Analiza składu chemicznego wskazuje na nieznaczne zmiany zawartości podstawowych pierwiastków stopowych dla stali niestopowych, tj. węgla (C), manganu (Mn) i krzemu (Si). Obserwowany jest wzrost zawartości tych pierwiastków od $0,2 \%$ wag. węgla dla stali o gwarantowanej granicy plastyczności $235 \mathrm{MPa}$ do 0,25\% wag. węgla w stalach o wysokiej wytrzymałości, gdzie granica plastyczności jest prawie pięciokrotnie wyższa, tj. $1300 \mathrm{MPa}$. Stale o wysokiej wytrzymałości, tj. S1100Q i S1300Q mają jednak niższą zawartość manganu i krzemu niż stale w zakresie granicy plastyczności od $460 \mathrm{MPa}$ do $960 \mathrm{MPa}$. Wskazuje to, że dla tych stali proces kontrolowanego nagrzewania i chłodzenia podczas walcowania i położenie temperatury austenityzowania i ilości węglików mają istotne znaczenie. W zakresie zanieczyszczeń widoczna jest tendencja dla ich znacznego ograniczania, w szczególności dla siarki. Dodatkowo w stalach o wysokiej wytrzymałości występują mikrododatki i dodatki stopowe znacznie poprawiające właściwości wytrzymałościowe uzyskiwane w wyniku obróbki cieplnej. Pierwiastki te występują również w stalach o wysokiej wytrzymałości, jakimi są stale o gwarantowanej granicy plastyczności powyżej 1000 MPa.
Porównanie składów chemicznych z właściwościami mechanicznymi [3 $\div 5$ ] wskazuje, że wzrost gwarantowanej granicy plastyczności i wytrzymałości na rozciąganie realizowany jest kosztem plastyczności stali. Powoduje to utrudnioną jej obróbkę plastyczną oraz wskazuje na wzrost skłonności do pęknięć gorących (podczas spawania lub tuż po procesie, kiedy materiał jest silnie nagrzany) lub zimnych związanych z występowaniem naprężeń własnych (rozciągających) w spoinie i obszarze przyległym, ryzykiem wystąpienia wodoru i „twardej” struktury charakterystycznej dla stali po obróbce cieplnej np. bainitycznej lub martenzytycznej.

Na właściwości mechaniczne stali wpływają dwa czynniki tj. proces wytwarzania obejmujący szereg procesów oddziaływania walców wraz z wielokrotnym nagrzewaniem do ściśle określonej temperatury i z określoną prędkością chłodzonej oraz skład chemiczny stali. Każdy z dodawanych pierwiastków powoduje określone zachowanie się stali podczas procesu walcowania i wpływa na uzyskiwanie określonej struktury stali. Podstawowym pierwiastkiem stali jest węgiel, który może występować w roztworach tj. ferrycie lub austenicie. Konieczny jest do tworzenia się cementytu i innych węglików oraz perlitu, bainitu i martenzytu. Wraz ze wzrostem zawartości węgla rośnie wytrzymałość i twardość stali, ale zmniejszeniu ulegają ciągliwość i odporność na pękanie. Istotnie wpływa na hartowność stali, gdzie wzrost zawartości tego pierwiastka odpowiada za twardość martenzytu i położenie (obniżenie) temperatury $\mathrm{M}_{\mathrm{s}}$ i $\mathrm{M}_{\mathrm{f}}$. Dodatkowo wzrost zawartości węgla zmienia takie właściwości fizyczne jak współczynnik rozszerzalności cieplnej (rośnie) i przewodności cieplnej (maleje), co przyczynia się do wzrostu naprężeń cieplnych $[1 \div 3]$.

Tablica I. Skład chemiczny i wybrane właściwości mechaniczne stali niestopowych o zwykłej, podwyższonej i wysokiej wytrzymałości wg PN-EN 10025-1 i PN-EN 10025-6 oraz dane SSAB i TyssenKrupp Steel [4,5]

Table I. Chemical composition and selected mechanical properties of non-alloy steels and high-strength non-alloy steels acc. to PN-EN 10025-1, PN-EN 10025-6 and manufacturer datasheet SSAB and TyssenKrupp Steel $[4,5]$

\begin{tabular}{|c|c|c|c|c|c|c|c|c|c|c|}
\hline Znak stali & $\begin{array}{c}\text { C, } \\
\% \text { wag. } \\
\max \end{array}$ & $\begin{array}{l}\text { Mn, } \\
\% \text { wag. } \\
\text { max }\end{array}$ & $\begin{array}{c}\mathrm{Si}, \\
\% \text { wag. } \\
\max \end{array}$ & $\begin{array}{c}P, \\
\% \text { wag. } \\
\max \end{array}$ & $\begin{array}{c}\mathrm{S}, \\
\% \text { wag. } \\
\max \end{array}$ & $\begin{array}{c}\text { Inne, } \\
\text { \% wag. } \\
\max \end{array}$ & $\mathrm{R}_{\mathrm{e}}, \mathrm{MPa}$ & $\mathbf{R}_{\mathrm{m}}, \mathbf{M P a}$ & $A, \%$ & Źródło \\
\hline S235JR & 0,2 & 1,4 & \multirow{2}{*}{ - } & \multirow{3}{*}{0,045} & \multirow{3}{*}{0,045} & \multirow{3}{*}{$\mathrm{N}: 0,009$} & 235 & 340 & 26 & \multirow{3}{*}{ PN-EN 10025-1 } \\
\hline S275JR & 0,22 & 1,5 & & & & & 275 & 410 & 22 & \\
\hline S355JR & 0,24 & 1,6 & 0,55 & & & & 355 & 490 & 22 & \\
\hline S460Q & \multirow{4}{*}{0,2} & \multirow{4}{*}{1,7} & \multirow{4}{*}{0,8} & \multirow{4}{*}{$\leq 0,025$} & \multirow{4}{*}{$\leq 0,015$} & \multirow{4}{*}{$\begin{array}{c}\text { Cr: } 1,5 \\
\text { Ni: } 2,0 \\
\text { Mo: } 0,7 \\
\text { Cu: } 0,5 \\
\text { V: } 0,12 \\
\text { Nb: } 0,06 \\
\text { Ti: } 0,05 \\
\text { Zr: } 0,15 \\
\text { N: } 0,015 \\
\text { B: } 0,005\end{array}$} & 460 & $550 \div 720$ & 17 & \multirow{4}{*}{ PN-EN 10025-6 } \\
\hline S690Q & & & & & & & 690 & $770 \div 940$ & 14 & \\
\hline S890Q & & & & & & & 890 & $940 \div 1100$ & 11 & \\
\hline S960Q & & & & & & & 960 & $980 \div 1150$ & 10 & \\
\hline S1100Q & 0,21 & 1,4 & 0,5 & 0,02 & 0,005 & $\begin{array}{c}\text { Cr: } 0,8 \\
\text { Cu:0,3 } \\
\text { Ni: } 3,0 \\
\text { Mo: } 0,7 \\
\text { B: } 0,005\end{array}$ & 1100 & $1250 \div 1550$ & 8 & SSAB \\
\hline S1300Q & 0,25 & 1,4 & 0,5 & 0,015 & 0,005 & $\begin{array}{c}\text { Cr: } 0,8 \\
\text { Ni: } 2,0 \\
\text { Mo: } 0,7 \\
\text { V: } 0,08\end{array}$ & 1300 & $1400 \div 1700$ & 8 & $\begin{array}{c}\text { TyssenKrupp } \\
\text { Steel }\end{array}$ \\
\hline
\end{tabular}


Drugim z kolei jest mangan, który do $0,8 \%$ wag. pełni rolę pierwiastka wiążącego tlen (odtleniacz) i siarkę w procesach metalurgicznych wytwarzania stali. Związanie siarki w MnS powoduje ograniczenie występowanie niskotopliwej eutektyki Fe-FeS będącej główną przyczyną kruchości na gorąco stali, a jednocześnie poprawia skrawalność stali. Dodawany w ilościach $1 \div 2 \%$ wag. powoduje dodatkowo umocnienie roztworowe stali, rozdrobnienie ziarna ferrytu w stalach walcowanych na gorąco i poprawę hartowności w stalach obrabianych cieplnie [1].

Krzem dodawany jest jako podstawowy pierwiastek stopowy począwszy od stali o podwyższonej wytrzymałości tj. S355 w ilości od ok. 0,5\% wag. Podobnie jak mangan pełni rolę odtleniacza a w ilości od 0,5\% wag. do 1,0\% wag. powoduje umocnienie ferrytu bez zmniejszenia ciągliwości, a dodatkowo powoduje opóźnienie procesów podczas odpuszczania powodujących kruchość stali.

Pierwiastki takie jak chrom (Cr), molibden (Mo) czy wanad (V) tworzą w stali węgliki, zwiększając tym samym hartowność stali, przy czym temperatura rozpuszczalności węglików rośnie wraz z ich stabilnością i zawartością poszczególnego pierwiastka w stali. Wymaga to często podniesienia temperatury austenityzowania i odpuszczania. Innym pierwiastkiem dodawanym w niewielkiej ilości jest bor (B), który silnie zwiększa hartowność stali. Następuje to, gdy jest rozpuszczony w austenicie, gdyż segregując do granic ziarn austenitu hamuje zarodkowanie ferrytu [2].

Nikiel dodawany w ilości do 3\% wag. nie tworzy węglików, a jedynie nieznacznie obniża temperaturę $A c_{1}$ co ma kluczowe znacznie dla maksymalnej temperatury odpuszczania. Dodatkowo powoduje poprawę odporności na kruche pękanie, a więc znacznie rozszerza możliwość stosowania stali konstrukcyjnych w obniżonych temperaturach.

Niob i tytan są pierwiastkami posiadającymi silne powinowactwo do węgla i azotu, pozwalającymi na regulowanie zawartości tych pierwiastków w składzie chemicznym stali. Szczególnie kluczowym jest w tym przypadku ograniczenie wpływu azotu będącego przyczyną kruchości stali na skutek jej umocnienia.

\section{Materiał do badań}

Badania przeprowadzono na blachach ze stali o gwarantowanej granicy plastyczności $1300 \mathrm{MPa}$ o grubości $4 \mathrm{~mm}$. Zakres prac obejmował wykonanie doczołowych złączy spawanych oraz przeprowadzenie oceny mikrostruktury stali w oparciu o mikroskopię świetlną i skaningową mikroskopię elektronową oraz pomiary twardości w przekroju poprzecznym złącza spawanego. Badana stal w stanie dostawy była po obróbce cieplnej, w wyniku której uzyskano wysoką wytrzymałość. Skład chemiczny i wybrane właściwości mechaniczne stali wskazano w tablicy II.
Próby spawania przeprowadzono z wykorzystaniem $12 \mathrm{~kW}$ lasera dyskowego TruDisk 12002 z wykorzystaniem głowicy hybrydowej. Doprowadzenie wiązki laserowej realizowano przy wykorzystaniu światłowodu o średnicy 0,2 mm, dzięki czemu uzyskano średnicę ogniska ok. 0,4 mm. Ognisko wiązki zlokalizowane było na powierzchni łączonego materiału.

Blachy do spawania o grubości $4 \mathrm{~mm}$ wycinano przy wykorzystaniu obróbki strumieniowo ściernej (cięcie wodą), a następnie powierzchnie po cięciu szlifowano (obróbka mechaniczna). W wyniku tych zabiegów uzyskano dopasowanie brzegów do spawania i szczelinę pomiędzy łączonymi brzegami poniżej 0,1 mm (rys. 1a), co umożliwiło prowadzenie procesu spawania bez stosowania materiału dodatkowego. W celu zapobiegnięcia przemieszczania się elementów podczas spawania wykonano metodą TIG (141 wg PN-EN ISO 4063) spoiny sczepne (rys. 1b).
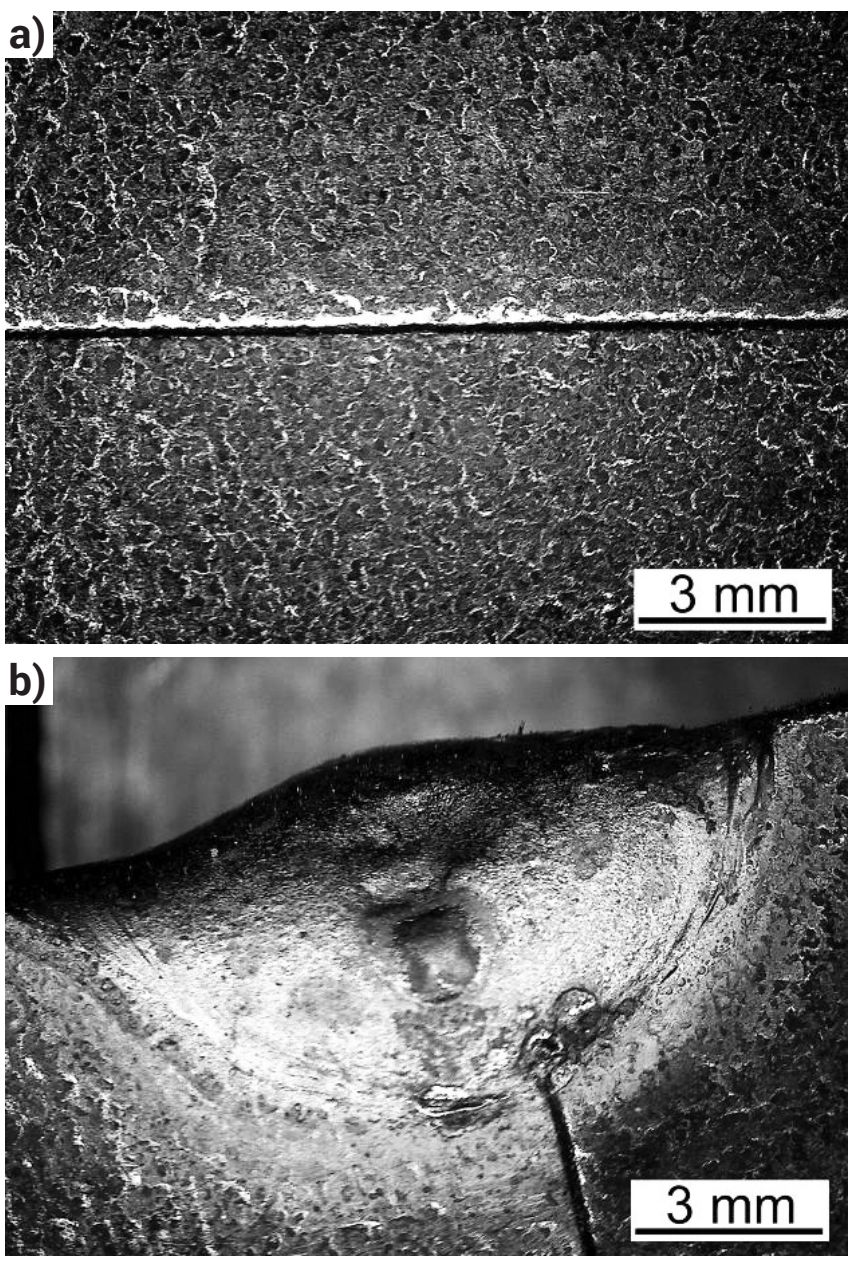

Rys. 1. Przygotowanie brzegów do spawania: a) szczelina pomiędzy łączonymi brzegami, b) spoina sczepna

Fig. 1. Edges for welding: a) gap between welded edges, b) tack weld

Tablica II. Skład chemiczny stali S1300QL

Table II. Chemical composition of S1300QL steel

\begin{tabular}{|c|c|c|c|c|c|c|c|c|c|}
\hline \multicolumn{10}{|c|}{ Maksymalna zawartość pierwiastków, \% masowe } \\
\hline C & $\mathrm{Si}$ & $\mathrm{Mn}$ & $P$ & S & $\mathrm{Cr}$ & $\mathrm{Cu}$ & $\mathrm{Ni}$ & Mo & B \\
\hline 0,25 & 0,50 & 1,40 & 0,020 & 0,005 & 0,80 & 0,30 & 3,00 & 0,70 & 0,005 \\
\hline \multicolumn{3}{|c|}{$\begin{array}{c}\text { Granica plastyczności } \\
\mathbf{R}_{\mathrm{p} 0,2}, \mathrm{MPa}\end{array}$} & \multicolumn{2}{|c|}{$\begin{array}{c}\text { Wytrzymałość na rozciąganie } \\
\mathrm{R}_{\mathrm{m}}, \mathrm{MPa}\end{array}$} & \multicolumn{2}{|c|}{$\begin{array}{c}\text { Wydłużenie } \\
A_{5}, \%\end{array}$} & & \multicolumn{2}{|c|}{$\begin{array}{l}\text { Praca tamania KV, J } \\
\text { w temp. }-40^{\circ} \mathrm{C}\end{array}$} \\
\hline \multicolumn{3}{|c|}{1300} & \multicolumn{2}{|c|}{$1400 \div 1700$} & \multicolumn{2}{|c|}{8} & & \multicolumn{2}{|c|}{27} \\
\hline
\end{tabular}



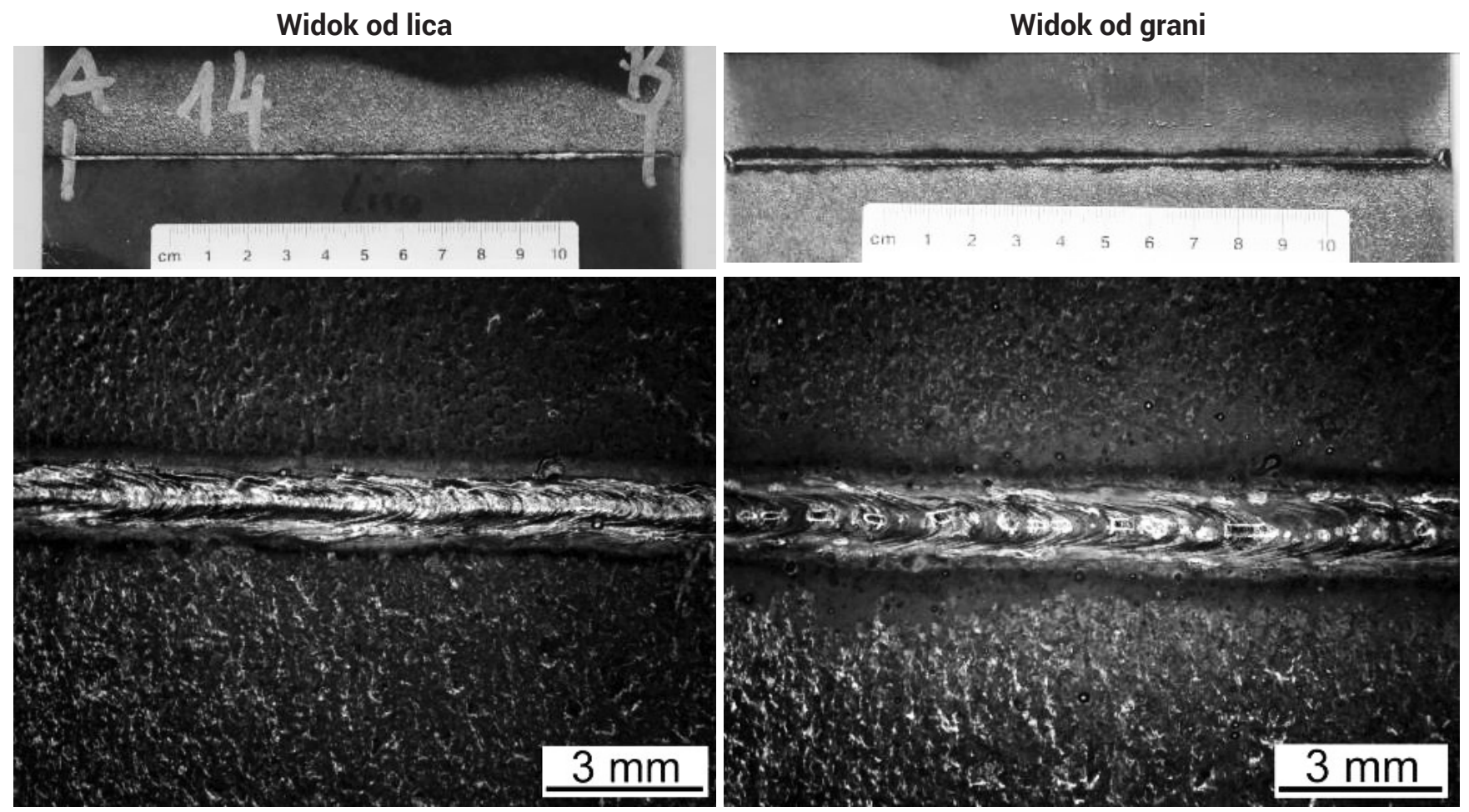

Rys. 2. Widok złącza spawanego blach o grubości $4 \mathrm{~mm}$ : widok ogólny złącza (górne fotografie) i widok makroskopowy (dolne fotografie)

Fig. 2. Welded joint of $4 \mathrm{~mm}$ thick plates: main view (upper figures) and macroscopic view (lower figures)

\section{Ocena wizualna}

Ocenę wizualną przeprowadzono spełniając wymagania wg PN-EN ISO 17635 i PN-EN ISO 17637 w oparciu o klasyfikację niezgodności wg PN-EN ISO 6520-1 oraz poziomy niezgodności wg wielkości geometrycznych (PN-EN ISO 13919-1). Wykonane złącze spełnia wymagania poziomu jakości B wg PN-EN 13919-1. W wyniku przeprowadzonych badań zaobserwowano lekko wypukłe lico i grań spoiny dla blach o grubości $4 \mathrm{~mm}$ (rys. 2).

\section{Badania makroskopowe}

Badania makroskopowe przeprowadzono na zgładach metalograficznych na próbkach pobranych w płaszczyźnie prostopadłej do osi spoiny, które poddano szlifowaniu mechanicznemu i trawieniu chemicznemu w $4 \%$ nitalu.

Obserwacje przy wykorzystaniu mikroskopii świetlnej pozwoliły ujawnić szerokość spoiny (ok. $1 \mathrm{~mm}$ ) oraz strefy wpływu ciepła ułożonej symetrycznie po obu stronach spoiny o zasięgu do $0,5 \mathrm{~mm}$. Linia wtopienia jest wyraźnie zarysowana. W obszarze lica zaobserwowano lekkie wklęśnięcie o głębokości do ok. 0,1 mm. Wklęśnięcie to występowało

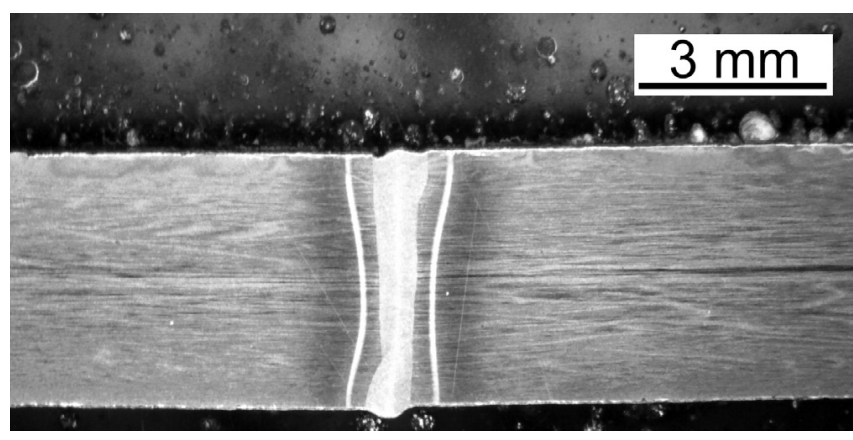

Rys. 3. Makrostruktura złącza spawanego

Fig. 3. Macrostructure of welded joint symetrycznie względem osi spoiny lub miało charakter jednostronny. Na zgładzie makroskopowym obserwowane są również duże krystality ułożone w kierunku odprowadzania ciepła. Pojedyncze krystality narastają od linii wtopienia do strefy transkrystalizacji w osi spoiny. Przykładową makrostrukturę złącza spawanego z widocznym symetrycznym wklęśnięciem lica spoiny oraz ułożeniem krystalitów przedstawiono na rysunku 3.

\section{Badania mikroskopowe}

Badania mikroskopowe z wykorzystaniem mikroskopii świetlnej i skaningowej mikroskopii elektronowej przeprowadzono na zgładach metalograficznych szlifowanych i polerowanych mechanicznie, a następnie trawionych chemicznie w $4 \%$ nitalu.

$\mathrm{Na}$ rysunku 4 przedstawiono mikrostrukturę materiału rodzimego (MR), strefy wpływu ciepła (SWC) i spoiny po spawaniu wiązką lasera obserwowaną przy wykorzystaniu mikroskopii świetlnej. Materiał rodzimy charakteryzuje się drobnoziarnistą strukturą martenzytyczną i martenzytyczno-bainityczną z dyspersyjnymi wydzieleniami węglików i węglikoazotków występującymi na granicach listew martenzytu i w ich wnętrzu. Analizując skład chemiczny stali, należy się spodziewać, że węgliki i węglikoazotki typu MX utworzone zostały przy udziale takich pierwiastków jak Mo, V, Nb i Ti.

W SWC obserwowany jest rozrost ziarna i efekt odpuszczania. Charakteryzuje się ona trzema wyraźnymi strefami: przegrzania, normalizacji i częściowego przekrystalizowania. Dodatkowo za strefą częściowego przekrystalizowania obserwowane jest pojawienie się jasnych obszarów wynikających z odpuszczania stali i tworzenia się podziaren. W obszarze przegrzania następuje nieznaczny rozrost ziarna.

Spoina charakteryzuje się martenzytyczno-bainityczną strukturą grubokrystaliczną z widocznymi dużymi krystalitami ułożonymi w kierunku odprowadzania ciepła, tj. od linii wtopienia do osi spoiny. Wynika to z małej szerokości spoiny i szybkiego odprowadzenia ciepła do materiału rodzimego. 
W osi spoiny obserwowane jest zjawisko transkrystalizacji, czyli zachowania kierunku wzrostu krystalitu w osi spoiny na całej jej długości.

Obserwacje przy wykorzystaniu SEM ujawniły w materiale rodzimym granice ziarn byłego austenitu. Widoczne jest rozmieszczenie w stali dyspersyjnych wydzieleń węglików i węglikoazotków zlokalizowanych zarówno w granicach ziarn, jak i pomiędzy granicami listew martenzytu i w ich wnętrzu

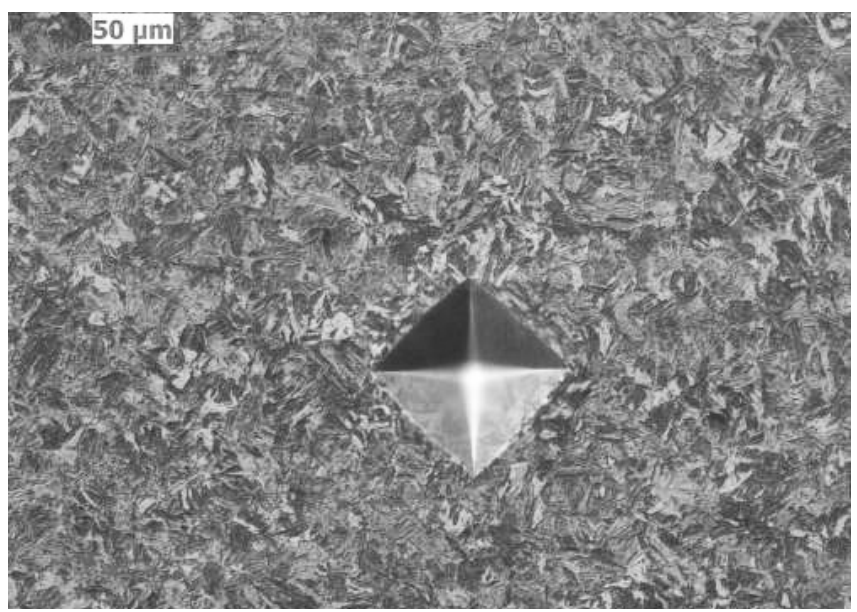

Struktura materiału rodzimego, struktura martenzytyczna, widoczny odcisk pomiaru twardości nr 3

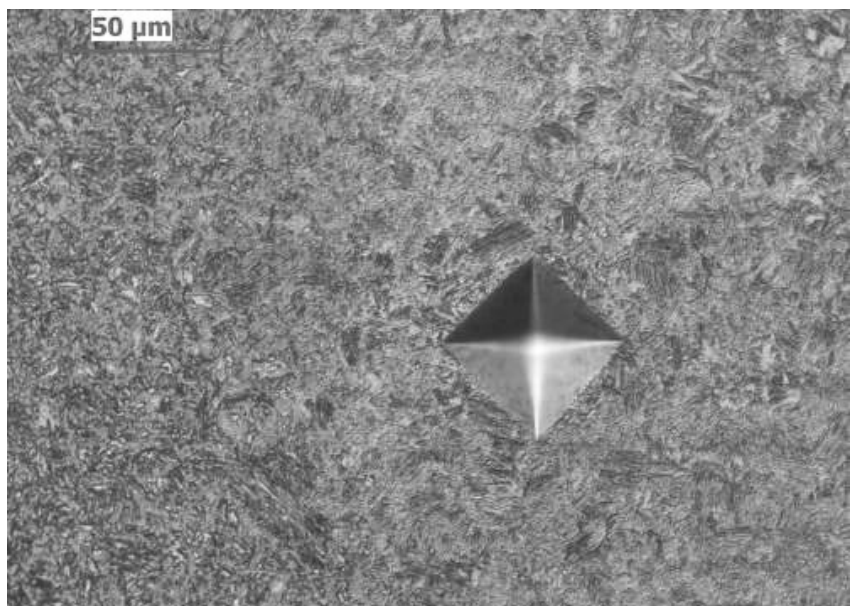

Struktura SWC, struktura martenzytu odpuszczonego, widoczny odcisk pomiaru twardości nr 11

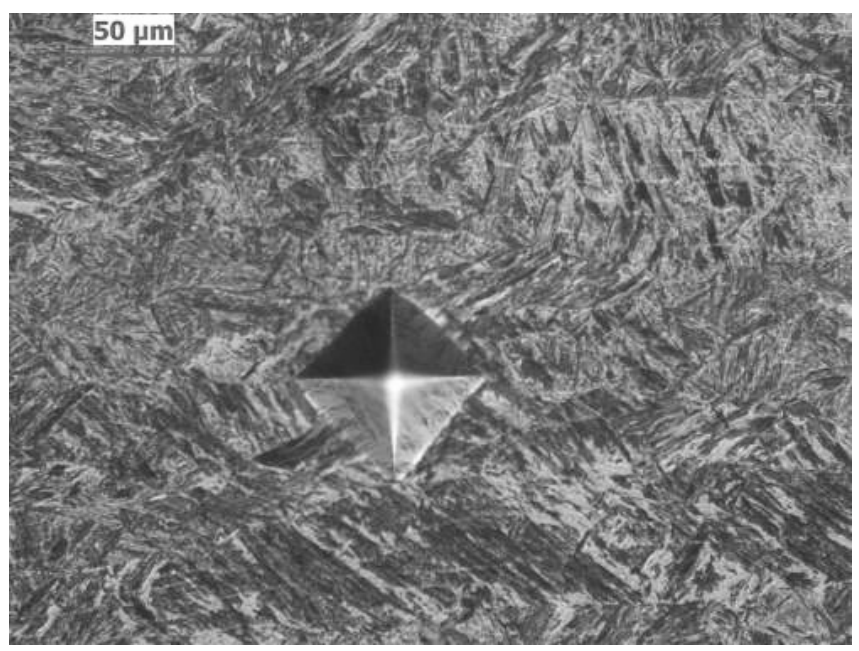

Struktura spoiny, struktura martenzytyczna, widoczny odcisk pomiaru twardości nr 14 (rys. 5a). W SWC (patrząc od MR) obserwowana jest struktura drobnoziarnista (rys. 5b), a dalej gruboziarnista struktura w strefie przegrzania (rys. 5c). W spoinie, z kolei, grubokrystaliczna struktura z widocznymi zarysowanymi granicami konglomeratów listew martenzytu o zbliżonej orientacji. We wszystkich obszarach obserwowane są dyspersyjne wydzielenia węglików i węglikoazotków, przy czym największa ich ilość obserwowana jest w obszarze materiału rodzimego.

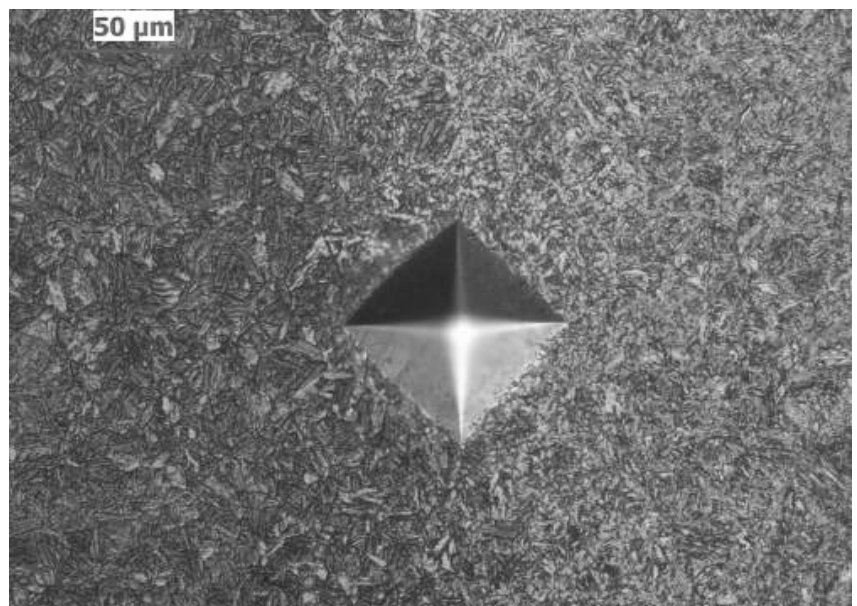

Struktura SWC, struktura martenzytyczna, widoczny odcisk pomiaru twardości nr 10

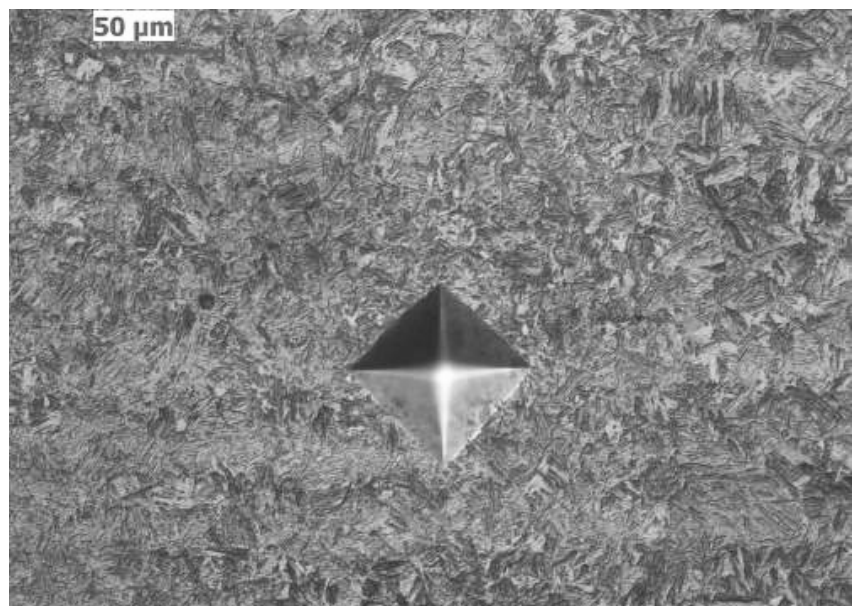

Struktura SWC, struktura martenzytu odpuszczonego, widoczny odcisk pomiaru twardości nr 12

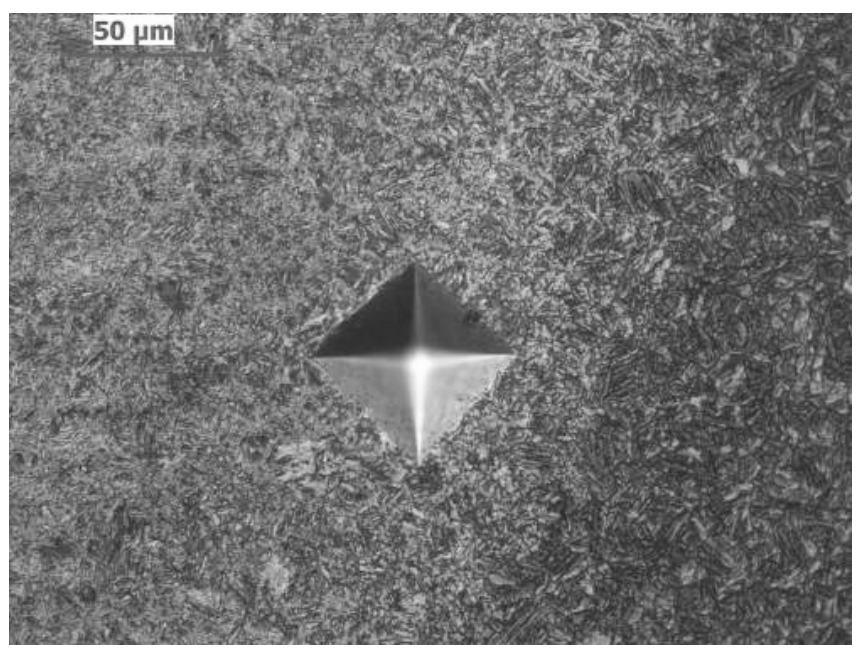

Struktura SWC, struktura martenzytyczna, widoczny odcisk pomiaru twardości nr 20

Rys. 4. Mikrostruktura złącza spawanego w charakterystycznych obszarach z widocznymi odciskami po pomiarze twardości metodą Vickersa Fig. 4. Microstructure of welded joint in specific zones with visible imprints after hardness measurement by Vickres method 

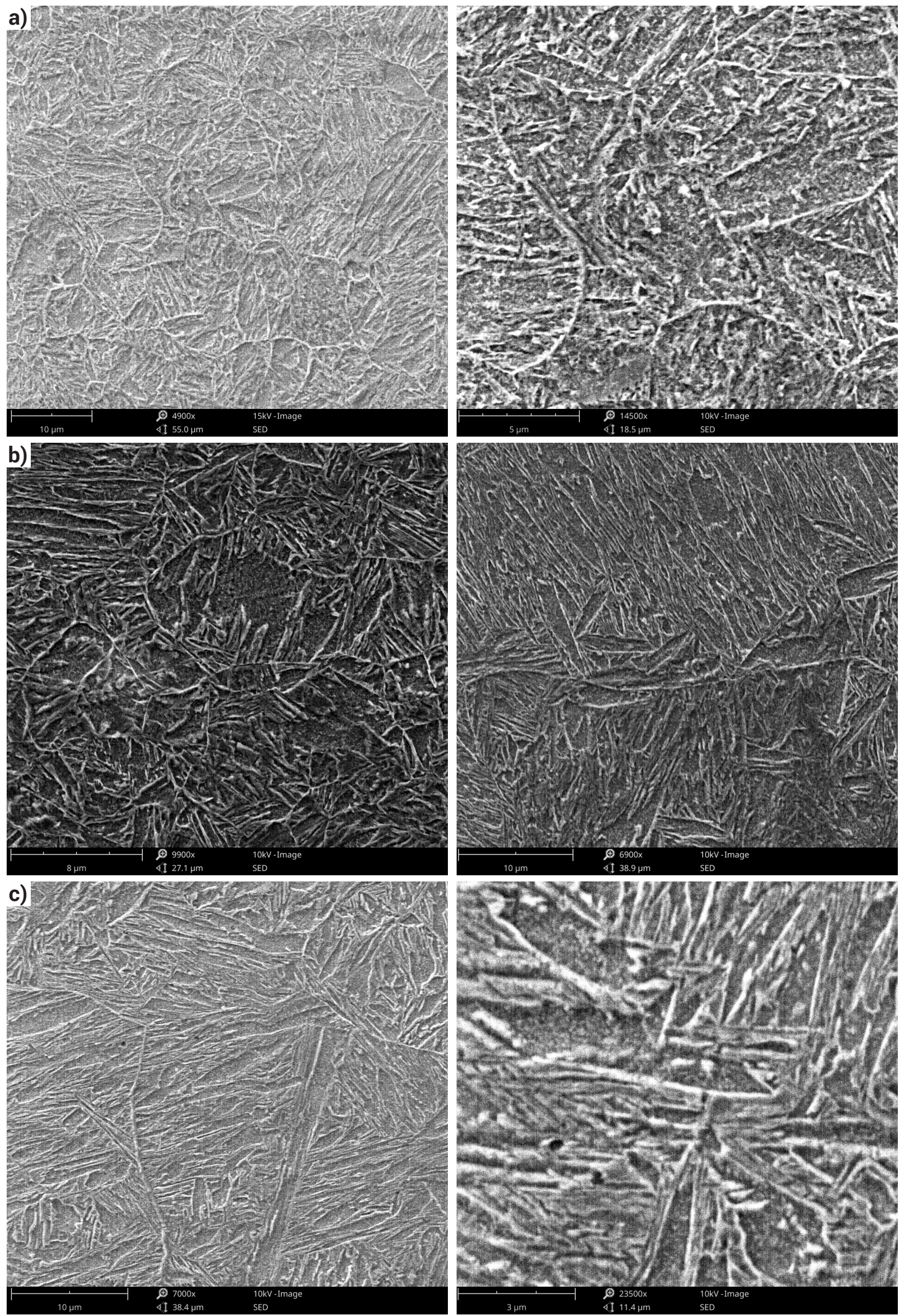

Rys. 5. Mikrostruktura złącza spawanego w charakterystycznych obszarach: a) materiał rodzimy, b) SWC, c) spoina

Fig. 5. Microstructure of welded joint in the specific zones: a) base metal, b) HAZ, c) weld 


\section{Pomiary twardości}

Pomiary twardości wykonano na zgładzie poprzecznym metodą Vickersa, stosując obciążenie wgłębnika 1 kG. Rozkład twardości wzdłuż linii pomiarowej obejmującej całą szerokość złącza spawanego przedstawiono na rysunku 6.

Widoczny jest wzrost twardości w obszarze spoiny do ok. 550 $600 \mathrm{HV} 1$ oraz występowanie strefy zmiękczenia w SWC, gdzie następuje spadek twardości do ok. 370 HV1. Strefa zmiękczenia zlokalizowana jest tuż przy strefie częściowego przekrystalizowania. Wskazuje to, że stosunkowo wysoka temperatura, ale niedostatecznie wysoka dla przemian fazowych, powoduje efekt odpuszczania stali, co prowadzi do jej zmiękczenia (spadku twardości). Wskazuje to, że najniekorzystniejszymi właściwościami mechanicznymi charakteryzować się będzie SWC. Należy się jednak spodziewać, że obserwowany spadek twardości nie będzie powodował znacznego obniżenia wytrzymałości na rozciąganie ze względu na zachodzące zjawisko wzmocnienia kontaktowego.

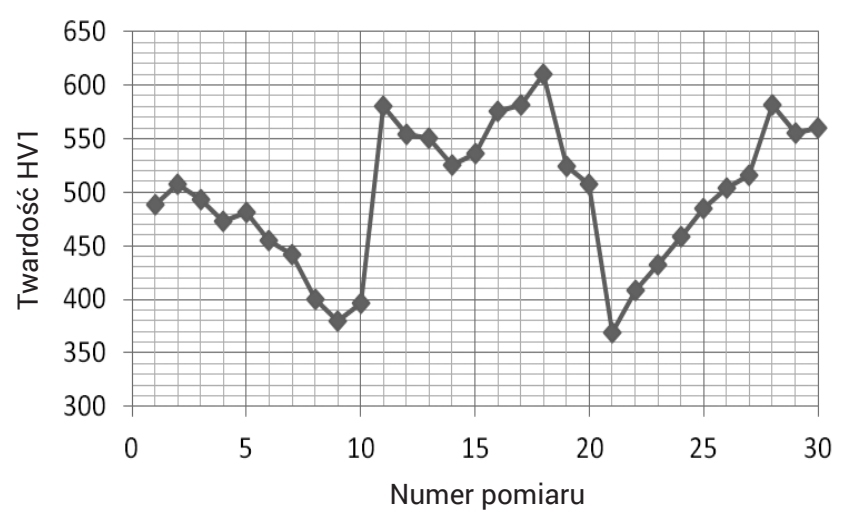

Rys. 6. Rozkład twardości w przekroju poprzecznym złącza spawanego

Fig. 6. Hardness distribustion in the coross section of welded joint

\section{Wnioski}

Na podstawie przeprowadzonych badań sformułowano następujące wnioski:

1. Proces spawania wiązką laserową zapewnia możliwość uzyskania złączy spawanych stali o wysokiej wytrzymałości wolnych od niezgodności spawalniczych,

2. Ocena wizualna ujawniła występowanie lekko wypukłego lica spoiny, co wskazuje, że wskutek prawidłowego przygotowania brzegów do spawania istnieje możliwość prowadzenia procesu spawania bez dodatku materiału dodatkowego,

3. Badania makroskopowe ujawniły występowanie lokalnie wklęśniętego lica spoiny przy spawaniu blach o grubości 4 mm i mikropustek gazowych na skutek ograniczenia możliwości odgazowania spoiny ze względu na szybki proces krystalizacji spoiny;

4. Badania mikroskopowe ujawniły drobnoziarnistą strukturę materiału rodzimego oraz strukturę martenzytyczno-bainityczną oraz martenzytu odpuszczonego w obszarze złącza spawanego z dużą ilością dyspersyjnych wydzieleń węglików i węglikoazotków; spoina zbudowana jest z dużych krystalitów kolumnowych z występującą strefą transkrystalizacji w osi spoiny;

5. Pomiary twardości ujawniły występowanie strefy zmiękczenia przy strefie częściowego przekrystalizowania; spoina charakteryzuje się nieznacznie wyższą twardością niż materiał rodzimy.

Praca realizowana w ramach badań przemysłowych na potrzeby realizacji projektu pt.: „Opracowanie i wdrożenie innowacyjnej, wysokowydajnej technologii łączenia stali wysokowytrzymałej o granicy plastyczności 1300 MPa wiązką laserową z wykorzystaniem zrobotyzowanego stanowiska" POIR.01.01.01-00-1072/15 (umowa nr 5.72.110.420).

\section{Literatura}

[1] E. Tasak: Metalurgia spawania, Wydawnictwo Jak, Kraków 2008.

[2] E.Tasak, A. Ziewiec: Spawalność materiałów konstrukcyjnych, tom 1: Spawalność stali, Wydawnictwo JAK, Kraków 2009.

[3] J. Pacyna: Stal na wyroby hutnicze, tom II Półwyroby i wyroby płaskie, Wydawnictwa Rolls-Rolls, Kraków 2016.
[4] www.ssab.com

[5] www.thyssenkrupp-steel.com 